\title{
ASSISTIVE TECHNOLOGY TO ENHANCE ACCESS TO INFORMATION FOR STUDENT WITH DISABILITIES A CASE STUDY IN SURABAYA
}

\author{
Fitri Mutia*, \& Indah Rachma Cahyani** \\ *Department of Library and Information Science, Universitas Airlangga \\ *Library of Universitas Airlangga \\ Email: fitri.mutia@fisip.unair.ac.id, indah.rachma@staf.unair.ac.id
}

(Submitted: 19-01-2021, Revised: 03-05-2021, Accepted: 07-05-2021)

DOI: $10.24252 /$ v9i1a3

\begin{abstract}
ABSTRAK: Akses informasi menjadi hal penting untuk mencapai keberhasilan pada setiap aspek kehidupan. Karena pentingnya, ini merupakan hak setiap warga negara tanpa terhalang oleh keterbatasan fisik atau mental. Penelitian ini bertujuan untuk menganalisis akses informasi yang mendukung mahasiswa disabilitas penglihatan dalam melakukan kegiatan pembelajaran di universitas. Tulisan ini menggunakan paradigma interpretif, yang bertujuan untuk menganalisis suatu realitas sosial dan bagaimana realitas itu terbentuk. Penelitian ini menggunakan tipe kualitatif yang berusaha memahami masalah sosial atau manusia, berdasarkan penciptaan gambaran holistik lengkap yang dibentuk dengan kata-kata, laporan pandangan informan secara rinci, dan dinarasikan secara alami. Penelitian ini dilakukan di Fakultas Ilmu Sosial dan Ilmu Politik Universitas Airlangga (Unair) Surabaya dengan melibatkan 11 informan, tiga di antaranya adalah mahasiswa disabilitas penglihatan. Informan pendukung ada 3 orang dosen Fakultas Ilmu Sosial dan Ilmu Politik Unair yang mengajar mahasiswa disabilitas penglihatan, 3 teman informan utama, 1 perwakilan universitas, dan 1 perwakilan fakultas. Hasil penelitian menunjukkan bahwa teknologi bantu yang telah mendukung proses pembelajaran, seperti telepon genggam, laptop, pemindai, dan alat perekam, disediakan secara mandiri. Teknologi tersebut sangat membantu untuk memperoleh informasi secara valid dan cepat, serta untuk memahami isi informasi dengan lebih mudah dan membantu untuk berbagi informasi dengan rekan-rekan lainnya.
\end{abstract}

Kata kunci: Akses informasi; teknologi bantu; orang dengan disabilitas penglihatan

ABSTRACT: Access to information becomes an important of achieving success in various aspects of life. Thus, it is considered the rights of every citizen without being impeded by physical or mental limitations. This study aims to analyze access to information that supports students with visual impairments (blind) in conducting learning activities at the university. This paper uses an interpretive paradigm, which aims to analyze a social reality and how that reality is formed. This research uses a qualitative type that seeks to understand social or human problems, based on the creation of a complete holistic picture that is formed with words, reports the views of informants in detail, and arranged in a natural setting. This research was conducted at the Social and Political Sciences Faculty of Universitas Airlangga (Unair) Surabaya, engaged 11 informants, three of whom were visually impaired students (blind). The supporting informants were 3 lecturers from the Faculty of Social and Political Sciences of Unair who teach visually impaired students, 3 friends of the main informant, 1 university representative, and 1 faculty representative. The study indicated that the assistive technologies have supported learning processes, such as mobile phones, laptops, scanners, and recording devices, were provided independently. The technology was very helpful to obtain information validly and quickly, as well as to understand the contents of the information more easily and assist to share the information with other colleagues.

Keywords: Access to Information; assistive technology; person with visual impairment 


\section{INTRODUCTION}

The emergence of information society era, which is marked by the use of technology in a massive way (Martin, 1995) as a medium for accessing information, has become an interesting discourse in society. Technology is necessary for gaining access to information equality. In recent years, the discussions on disabilities are primarily concerned with physical access such as sidewalks, automatic doors, special elevators and toilets, ramp for wheelchair users, etc.

WHO predicted that by 2020 the number of people with disabilities will increase, especially for the visually impaired whose number is estimated to reach 76 million worldwide (Drigas Athanasios, Kouremeneous Dimitris, 2007). In Indonesia, the data shows that the highest School Participation Rate occurred in students with disabilities aged 7-12 years (primary school level), standing at 41,227,360 (91.12\%) while the lowest is in students with disabilities aged 1924 year, at 5,870,880 (12.96\%). Furthermore, this data shows the low participation of students with disabilities at the university level (Databoks, 2019). The presence of visually impaired students requires the education institution to provide them with a broad and easy access to information. Access is a concept that is very influential in the lives of every individual. With the availability towards access, the equality rights are met despite any physical or mental limitations. The easiness of getting information through both informational technology and modern communication proves that physical and informational aspects are accessible (Jaeger, 2005).

Problems faced by visually impaired students with the access to digital and manual information are closely related to the limited technology infrastructure and types of media, such as laptops, cell phones with physical keyboard, mouse and braille printer, which have not yet to be taken full advantage of. Technology that can be easily used by all parties, including blind students, is a system that is created flexibly so that it can be directly used without modification or other supporting tools known as adaptive technology. The technology must be utilized as widely as possible by individuals with various characteristics of ability, in different environments, and be able to cover a very broad scope. The inability to, either partially or fully, visualise an object or physical event in accordance with reality hampers the students from accessing information.

The issue of inclusive campuses is a discourse that continues to be developed in the world of education in order to achieve equal rights for all students. This study examines access to information for students with visual disabilities at university levels because higher education students are required to obtain a lot of information to complete their education based on the competency standards set by the faculty. The research carried out in the city of Surabaya was also motivated by the statement of the Mayor of Surabaya, that since 2009 the city has pioneered, he inclusivity by maximizing the facilities needed for school students with disabilities, although these facilities are not yet provided for university students (Nurwawati, 2017). Universitas Airlangga is one of the universities in Surabaya which accepts visually impaired students, even though the campus has not yet to fully provide facilities and other support systems as to be considered an inclusive campus system. Since 2014, the Faculty of Social and Political Sciences of Universitas Airlangga has opened opportunities for students with visual disabilities to get together with general students to study in the anthropology, information science and libraries, and public policy study programs. Specifically, the faculty neither provides volunteers to accompany the students, not learning media in the form of assistive technology. Also, they have not yet to set up a specific institution which aims to cater all needs of and provide assistance for students with disabilities. Students with disabilities are expected to be able to survive in an inclusive environment independently

\section{PREVIOUS FINDINGS}

In Indonesia, research on disabilities has been carried out in institutions that have disability services and proclaimed as an inclusive university, research at the university takes students with disabilities as research subjects, for example, Universitas Brawijaya in 2016 by (Faizah, 
2016) researching the Quality of Life of First-Generation Students with Disabilities in Taking Education in Inclusive Higher Education. The results of Faizah's research stated that the quality of life of students with disabilities in studying at inclusive tertiary institutions tends to be different, some are positive but some are negative. Thesis (Mutadho, 2018), regarding the Political Policy Analysis of the UIN Sunan Kalijaga Campus and Gajah Mada University for the participation of students with disabilities, it is known that the results show that students with disabilities have not been fully given special space for their representation. Another study in 2018 with the title The Life Meaning of Unesa Disabled Students Who Become Volunteers at the Center for Disability Service Studies (PSLD), State University of Surabaya, on disabled students with disabilities and low vision disabilities who experience birth defects which were researched by (Naraswari, 2018). The results showed that the participants were able to tell their experiences while volunteering and could understand the disabilities they experienced so that finally they were able to accept themselves by actualizing their strengths and weaknesses. According to (Mutia, 2020) the adaptation of the higher education system to be inclusive, which offers appropriate support services, one of which is adaptive technology to access knowledge, is still not felt by visual disabilities. The educational achievement of and student is closely determined by a number of university value criteria, which of course often apply to students with disabilities. Ultimately, if a disabled student can fulfill his responsibilities through adaptive technologies like all students in general, the conditions of disabilities they encounter are always in question and their skills are the basis for achievement.

Conceptually, access to information for disabilities deals with equal opportunities of receiving and understanding information (Baumel., 2006). Information access refers to the ownership of information applied in critical and innovative thinking processes and encourages cognitive abilities for problem-solving. Included in the category of access to information are manual and electronic documents, information channels, as well as how information is grouped, organized, exhibited, served and disseminated to others.

Assistive technologies that can be used by visual impairment person include recording tools as a medium to "record" information, allowing access for those with visual disabilities to repeatedly listen for information without assistance (Sunanto, 2005). There are some other options for assistive technologies for the visually impaired; firstly, Voice communication, which enables person with visual impairment to talk with others about things which cannot be rely communicated via e-mail or text messages. This service is available in VoIP through Skype, Yahoo, and MSN Messenger. This software application can be installed on a computer desktop and Tablet PC, as well as several handheld devices. Some advantages of these softwares are: (i) there is no need to pay for a commercial license fee to get different features of sophisticated software; (ii) the features from Yahoo Messenger and Microsoft Network (MSN) Messenger can be adjusted efficiently and effectively. Secondly, handwriting recognition technology enables the students to take notes and save these notes in PDF or MS Word document format. Thirdly, voice recognition, combined with pen-based keyboard, helps its users communicate face-to-face with each other. These technologies rely much on sound signals, such as media players on mobile phones to listen for information, and Optical Character Recognition (OCR) (Alzahir in Pablos et.al., 2011).

Availability of access is an important issue in the life of those with disabilities. Improved access plays a key role in supporting the success of the students to obtain information, both offline and online. Promoting the equality in access to information available in electronic media (e-content) has always become the main goal of web designers today; this is because information access is a pivotal aspect in Communication Technology (ICT) and internet services. Online environment is able to provide opportunities for wider interaction for students with visual impairments although it still poses some problems for them due to limitations. The pressure from the community, marginalization, exclusion and other life experiences faced by this group, unwittingly creates awareness and cultural ties between them. These conditions create a desire to share experiences with each other, and a sense of solidarity that can support the realization towards inclusion access and rights as citizens among them. 


\section{RESEARCH METHODOLOGY}

This research relies on interpretative paradigm, which aims at analysing a social reality as well as how this reality is shaped. Also, this qualitative research attempts to comprehend a social problem based on the holistic view made up of words, to report the informants' viewpoints thoroughly which are compiled out of its nature (Gibbs, 2021). This research was done using visually impaired students sampled from the Faculty of Social Science and Politics at Universitas Airlangga due to the fact that at the university level, this group of people is believed to have been able to decide on which information needed in addition to the fact that their needs for information are somehow more complex compared to those at high school level.

Data in this research is obtained from different approaches which range from in-depth interviews, observation to literature review (Bungin, 2007). The former was conducted with all the informants as many as one to three times and lasted two to three hours at each session in order to extend the discussion on how these informants get along with the disabled at campus, and how they get information using adaptive technologies. To get a detailed description of the interviews, the researcher conducts a triangulation through which extra informants are interviewed so as to obtain varied and complete data out of this research.

The primary subjects of this research are university students with visual visual impairments who find difficulty getting access to information either manually or digitally. These students are registered at FISIP Unair and are taking a bachelor's degree in Anthropology, Library and Information Science, and a master's degree in Public Policy respectively. The other eight informants help corroborate triangular data, i.e. three lecturers at Fisip Universitas Airlangga who have been teaching the aforementioned students (ES, TS and Sa), three friends of these students (AR, SY and KF), a representative informant of the university (KS) and one from Faculty of Fisip Unair.

\section{RESULTS AND FINDINGS}

The procedure for data analysis comprises 1) interviewing the informants about their experience in living as a student at Unair as well as getting access to information, 2) transcribing the results of these interviews out of the data collected on the basis of the account which shows the informants' identity and how they perceive themselves, 3) reducing the collected data by picking out and abstracting the informants' experience of getting access to information as per individual, which is retrieved from the encoded field records, 4) interpreting the account thematically, 5) conducting a triangulation to prove the data as well as further discuss the findings, and 6) arranging the report chronologically by the meaning of the account.

In the era of information society, every individual has the rights to access the information they need, including students with visual impairments. Assistive technology has made it easier for people with disabilities to obtain, understand, and share information with others. Discourse regarding access to information for students with visual disabilities is an important issue for the management of educational institutions to consider today. The number of students with disabilities is not small and tends to increase every year. This has become a part of the academic community and so has their involvement in every activity.

According to lecturer SA, Access to information is the rights of every person, especially in the current era of information disclosure, access to information resources must always be available, as it is protected by the law. For students with visual impairment, access to information becomes a liaison that can help them to complete lecture assignments easily, increase knowledge, and interact in an academic setting, even though the availability of access is not yet widely available. As stated by informant AA, accessibility should not be a problem that prevents people with disability from doing anything. AA asserted that in a location where there is no physical or information access available, the independence of people with disability is challenged. They must be able to take advantage of existing facilities as much as possible regardless the limitations and obstacles imposed by the lack of environmental concern. If they 
only wait to be provided with facilities (assistive technology, digital text) by the government or educational institutions, then they will find it difficult to grow up or become an independent person in achieving their ideals as an inclusive in society.

New computer technology has developed a lot of softwares to facilitate these students to read, write, store and share information and knowledge. In regard to these technological advances, students with visual impairments need to be prepared so that they can easily access modern technology. Developments in information and technology (IT) in the scope of IT-based assistive technology can facilitate independence, security, and improve the quality of life of someone with a disability. Utilization of knowledge possessed by a person with disabilities and supported by access to information can expand their ability to become independent and qualified individuals. Informant DD stated that, With the help of information technology, now he able to find information that He wants and can obtain information at any time without having to wait for help from other parties. the media which often help these three students in class include cell phones and laptops. This is in accordance with the statement spoken by the student with visual impairment, AA, he usually searches for information on the internet. If the lecturer explains in class, he records using a cell phone or laptop. That is very useful as a lecture note, and he can repeat it at home so I can understand more about the material.

Students with visual impairments certainly have different needs in virtual space compared to normal individuals, but these needs have not been a major concern of technology designers and developers. The application of modern technology in educational environments such as computer rooms, networks between classrooms, multimedia classrooms, and so on Have not met the standards or friendly to them (Jingyuan in Pablos, et.all, 2011). In addition, when using existing technology, students with visual impairments also need a relatively longer time to adjust. The different functions which co-exist between old and new technologies also affect the difficulty of students with impairments to access information through it.

The impediment to this information was studied in the research conducted by (Duplaga, 2017), which states that the condition of visual impairment can increase digital disparities caused by low economic status (inadequate finances) or lack of skills and facilities which prevents them from benefitting from access to information through modern technology. The availability of technology that is less accessible to students with disabilities certainly becomes a dilemma, because on the one hand, they hope to be able to access information so that they can actively participate in society, but on the other hand the lack of available information technology prevents the students with impairments to use of technology freely.

Access to information needs to be built as an adequate system so that information is easily obtained by anyone who needs it and strengthens the bottom-up mechanisms in communitycentred development. The system in question is not just a technology system, but also in the form of diverse media so that everyone can use the system to obtain information (Oltmann, 2009). Individuals and communities need to develop skills and resources to obtain, share, create, and disseminate information, so as to create strong mechanisms in overcoming challenges.

The need for access to information is very dominant in higher education because students are required to do critical thinking, such as conducting research, and comprehensive information is needed from a broad source of information (Smethurst, 1999). Access to learning material is an important factor for students in achieving success in education. Hence, visual impairment students need access to diverse sources of information for study and research material, although information facilities are not always available to meet their needs.

Assistive technology available to students with visual impairments in the form of alternative communication devices or computer-based voice recognition to access information requires effort and independence from blind students. Thus, technology is a trigger for success and is not a barrier to blind student activity. Lecturer TS stated that student AA and DD with visual impairments (who have had total visual impairment since infancy) are able to use assistive technology to support their lecture activities because they have been accustomed to using this technology since they were educated at the Blind Children Foundation in junior high 
school. In contrast to MP who experiences blindness while studying at Universitas Airlangga (due to illness), she is still in the process of learning assistive technology and slowly showing progress, but still requires repeated training to get used to using the media.

Since information technology has become an important basis for the development of modern education, it must be utilized to seize comprehensive opportunities in the construction of computer-based information and communication networks (Patricia Ordóñez de Pablos, Jingyuan Zhao, 2011). In the era of information society today, technology plays a big role in facilitating students with visual disabilities to access information quickly and accurately. All assistive technologies are created to familiarize students with visual disabilities so that they can become part of the information society. Previously, they were only able to access information through braille by utilizing the sense of touch. Now, they can use assistive technology in the form of JAWS (Job Access with Speech) and NVDA (Non-Visual Desktop Access), software which allows people with visual impairment (blind) to "read" the writing on the monitor screen (Freedom Scientific, 2019). The software JAWS has been present since 1989 but started to be used by students AA and DD around 2012. Meanwhile, NVDA, which was introduced in 2006, is more often used by MP. Based on the information from AA and DD, they have been using JAWS for so long that they feel more comfortable with it than with NVDA. The usage of the software is ubiquitous among people with visual impairments because it is thought to be very helpful in accessing information, although there are still limitations regarding their ability to use it. the other software which can be used and functions as an information access device are the speech access program Outspoken and Digital Equipment Corporation (DECtalk). The presence of this assistive technology according to lecturer TS not only helps students with visual disabilities to access information easily, but also provides opportunities for them to plan their careers in the future by engaging in formal work.

Discourse about blind students in the world of education continues to be echoed, for example by arranging an inclusive curriculum system, diverse learning media, providing assistive technology and software, innovative teaching techniques and so on. On one hand, it was done with the aim that students with visual impairment can easily adapt to the general education environment, but on the other hand the education environment also understands how to behave towards them, opens opportunities to participate without limits, and in fact, it is able to eliminate stigma. It is intended to maximize their cognitive, social and affective abilities, in the hope that students with visual impairments are able to become subjects in various aspects of life which are broad and full of challenges.

As technology is increasingly used in various aspects of life, the lecture process must be balanced with information access facilities by educational institutions. Unfortunately, this has not yet been realized at the Faculty of Social and Political Sciences of Universitas Airlangga, despite the fact that this university has accepted students with disabilities, it has not yet implemented an inclusive curriculum. Lecturers in the Social Science study program, for example, which admits students with visual impairments actually welcomed the efforts towards an inclusive campus within the faculty. However, as the front guard dealing directly with students with visual impairments, they need to be equipped with adequate knowledge about how to interact and teaching strategies for students with disabilities as well as equipment to facilitate the teaching and learning process in class. Lecturer SE revealed, If the faculty accepts students with disabilities, they must provide the facilities, because this is everyone's right. Lecturer SE is concerned about the learning activities of students with visual impairments if the Faculty of Social and Political Sciences of Universitas Airlangga has not prepared themselves as an inclusive university, but has admitted them. The limited socialization of the faculties and universities regarding the acceptance of blind students at Universitas Airlangga surprised the lecturers since they have not yet to be ready for them in the classroom. This is justified by the statement of KS as a university representative saying that to date, the efforts made by the management of Universitas Airlangga to facilitate students with disabilities have not reached the policy level, because the university does not have a policy about it, so it all happened suddenly. 
A similar sentiment was also expressed by an informant from the Faculty of Social and Political Sciences, Universitas Airlangga, MD.

The study process of students with visual disabilities in the general education environment, in certain aspects, requires the help of other parties, for example from a companion or volunteer provided by the university to help the disabled with the activities on campus. During this time, students with visual impairments are often assisted by their classmates to access the lecture room, including accessing information. Based on the information from student MP's classmates, AR, SY and KF, it is known that, When she goes to class, MP's classmates sometimes help to record lecture material, except when the classes are done and it is almost midterm or final exam, MP's classmates take photos of her notes and send it to MP via Whatsapp or copy it directly to her laptop. (AR), while SY revealed, in class, she helped by lending notes and downloading journals. The statement was confirmed by KF who revealed, If MP asks about assignments or course material, she helps explain it, show chairs, and record class materials.

Students with visual impairments must be able to utilize the technology without modifying or adding additional tools in its usage. When a technology company designs a product, it must take account of the use of the product by individuals with disabilities so that their market share becomes wider. Assistive technology is a solution to assist people with disability accessing information, since inclusive technology is an alternative medium that can be used by all members of society. Before the advent of assistive technology, visual impairment students desperately needed help from others, which had an impact on their independence. Adaptive computert software and hardware can help students with visual impairments interact, complete college assignments, and complete routine daily activities. It is hoped that, access to information through information and communication technology (ICT) makes it easy for every individual to get information and conduct interaction and communication more broadly.

Based on the descriptions above, it can be seen that some of the media used by students with visual disabilities in accessing information, are shown in table 1 below:

Table 1. The Type of Media to Access Information

\begin{tabular}{|c|c|c|}
\hline Category & Media type & Informant \\
\hline $\mathbf{C}$ & & DD \& AA \\
\hline \multirow{5}{*}{$\begin{array}{c}\mathbf{O} \\
\mathbf{N} \\
\mathbf{V} \\
\mathbf{E} \\
\mathbf{N} \\
\mathbf{T} \\
\mathbf{I} \\
\mathbf{O} \\
\mathbf{N} \\
\mathbf{A} \\
\mathbf{L}\end{array}$} & Braille & $\begin{array}{l}\text { Reading and writing in braille are difficult because they take } \\
\text { more time and space to write. }\end{array}$ \\
\hline & $\begin{array}{l}\text { Read by } \\
\text { others } \\
\text { (family, } \\
\text { friends) }\end{array}$ & $\begin{array}{l}\text { DD, AA \& MP } \\
\text { requires the role of others (friends, parents, other family } \\
\text { members) to read texts in books and on social media. }\end{array}$ \\
\hline & & AA \& DD \\
\hline & $\begin{array}{l}\text { Cassette } \\
\text { recorder }\end{array}$ & $\begin{array}{l}\text { When studying in high school, this media was used to record } \\
\text { learning material, but when at university this media was } \\
\text { abandoned }\end{array}$ \\
\hline & Software & \\
\hline \multirow{6}{*}{$\begin{array}{l}\mathbf{M} \\
\mathbf{O} \\
\mathbf{D} \\
\mathbf{E} \\
\mathbf{R} \\
\mathbf{N}\end{array}$} & & AA \& DD \\
\hline & JAWS & - Easy to operate \\
\hline & & - More comfortable because they have been accustomed \\
\hline & & MP \\
\hline & NVDA & $\begin{array}{ll}\text { Media that was first used up } & \begin{array}{l}\text { Occasionally using } \\
\text { alternating with JAWS }\end{array} \\
\text { to now } & \end{array}$ \\
\hline & Hardware & AA, DD, \& MP \\
\hline
\end{tabular}




\begin{tabular}{cl}
\hline Cell Phone & $\begin{array}{l}\text { Used to record lecture material, save files, and to communicate } \\
\text { with the environment (order a motorcycle service, SMS, social } \\
\text { media) } \\
\text { Used to work on college assignments, record lecture material, } \\
\text { interact on social media and search for information related to } \\
\text { lectures (search engines) } \\
\text { Scanner }\end{array} \quad \begin{array}{l}\text { Used to convert printed files to digital then read using software } \\
\text { (JAWS / NVDA) }\end{array}$ \\
\hline
\end{tabular}

Sources: Processed primary data

Based on the findings of this study, it is known that there are two types of media used by students with visual impairments in accessing information, namely conventional and modern. Conventionally, disability used to process information through writing in braille, as stated by DD, bye which he had used braille as a medium for reading and writing information. Using braille takes more time and space than writing. However, the use of braille in reading and writing are still widely used in special educational activities for students with visual impairments. Besides using braille, another method is to have the materials read by friends or close family to find out the contents of the information, and use a tape cassette recorder. While the modern media that they now use are JAWS and NVDA screen reader software, in practice there are still obstacles when accessing digital information in the form of tables, pictures or graphics that appear on the screen. As for hardware media such as cell phones and laptops, they are not only used to record lecture material but are often used to interact with the surrounding environment (social media). While the media scanner is used to convert printed files to digital, which is then "read" using JAWS or NVDA.

Availability towards access to information refers to the ownership of information widely and in large quantities, so that it can be used in the process of critical thinking and encourage the emergence of innovative thinking abilities. To achieve this, accessing information widely in the conventional way is less efficient, because people with visual impairments are expected to access it manually (Sunanto, 2005). The development of modern technology that is appropriate is one way to reintegrate disability in the world of education because it facilitates disability in interacting or working with others so as to achieve common goals according to the standard of human life in general (Damaj, 2008). This was confirmed by lecturer SA that, the development of modern assistive technology can provide ease in accessing and understanding the content of information for visual disabilities, so they do not need to carry thick and heavy printed books. Modern technology in the form software and hardware also allows the visually disabled to operate smartphones, laptops or computers to interact with the wider community by maximizing their sense of hearing (audio). According to the informant representing the university, KS, the role of technology for people with disability is so great that now information can be accessed more freely through the sense of hearing than sense of touch, such as using braille. However, modern technology does not necessarily make people with disability abandon the conventional methods, as experienced by MP, in some cases it is difficult to adapt to the new technology learned, as she expressed that She still need someone else to read the contents of the information on the cell phone, or on the laptop. Sometimes she still clicks on the wrong thing, because she is not used to it. Her mother often tells her what appears on the screen. Based on the type of media used by key informants (students with visual disabilities in accessing information both conventional and modern), both types of media appear to have advantages and disadvantages in their use, as shown in the following table: 
Table 2. Weaknesses and Strengths of the Media

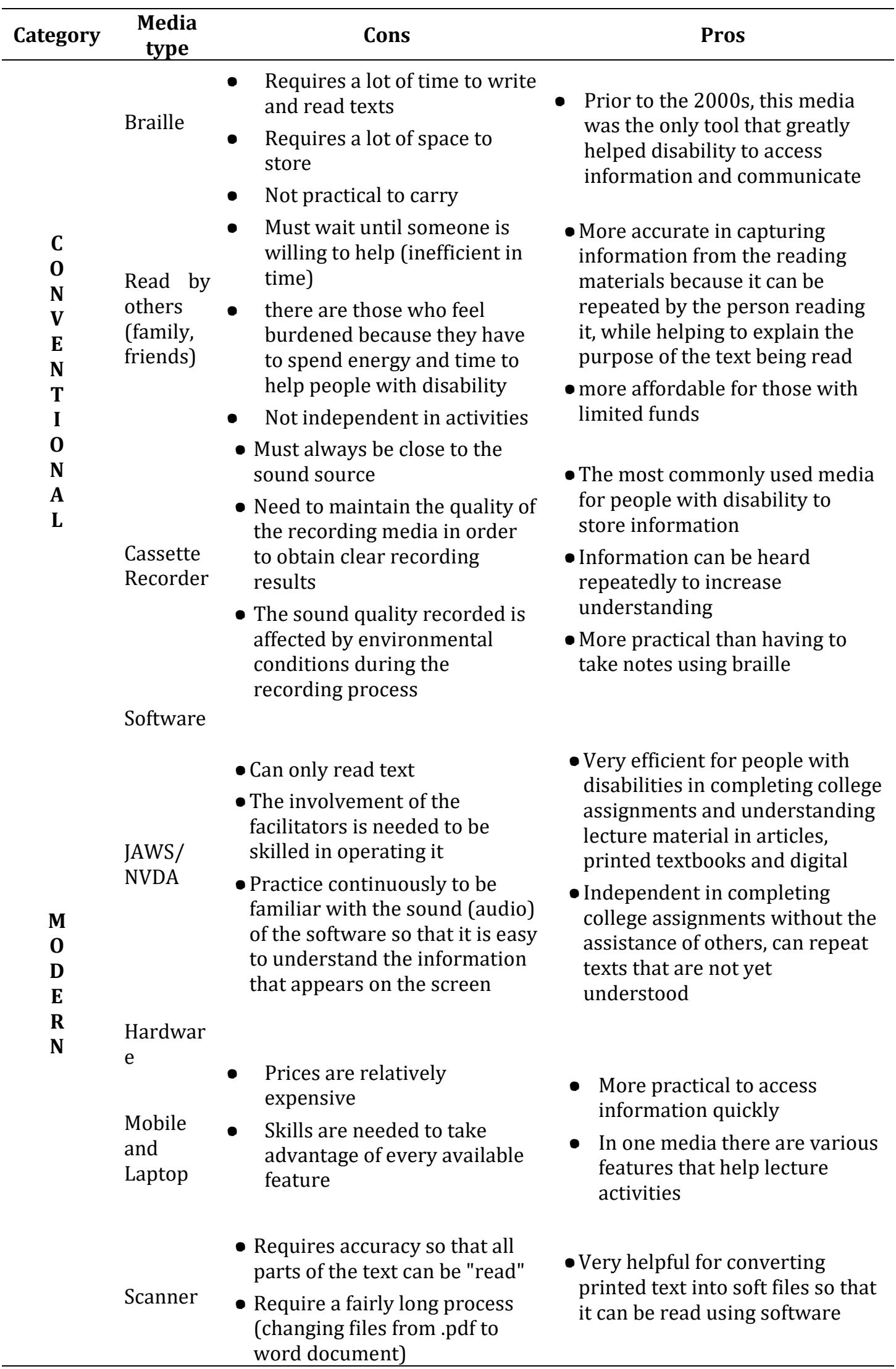

Sources: Processed primary data 
Screen reader software such as JAWS or NVDA that simulates human speech into text on a computer screen (Dawn, 2013) is used to facilitate people with visual impairments in reading books, articles and accessing other printed information. Information in digital format is considered more capable of meeting the specific needs of students with visual disabilities. Hence, technology useful for reading various formats including tables, graphs and images, needs to be developed.

The presence of technology has provided opportunities for students with visual disabilities to access information and complete assignments efficiently and enable them to achieve a certain level of independence. (Kelly \& Smith, 2011) also revealed that technology is able to promote literacy skills, provide wider access to information for education, employment, and facilitate social networking for people with disabilities and help them to actively participate in future interactions. Much as it is cheaper to create a physically accessible building from the start rather than retrofitting, wireless connectivity is often easiest and more cost efficient to accomplish as it is considered from the start of a product cycle. ICT goods and programs can be established without regard for usability requirements and rules, potentially excluding those individuals with disabilities who need these services. There is a critical need to increase stakeholder capacity on how ICT affects people with disabilities, as well as the wide range of accessible and low-cost connectivity options available. Many people with disabilities, their families, and disability care providers, particularly in low- and middle-income countries, are affected by this (Raja, 2016).

To achieve this, blind students must be facilitated with a learning environment that provides equal access through the curriculum, competent teaching staff, and other adequate support systems. According to a WebAIM survey published on the web in May 2012, the two most commonly used screen reader app applications are JAWS (Job Access with Speech) and NVDA (NonVisual Desktop Access). The most famous screen reader is JAWS, which is followed by NVDA. This is in line with global figures, which show that JAWS is the most common screen reader, with NVDA coming in second (Mccarthy \& Cutrell, 2014).

The problem is not only related to designing media for satisfactory mobility but it is necessary to identify optimal information in order to form independence, such as making software and hardware at a reasonable price so that training disability is familiar with assistive technology. In low- and middle-income nations, where public support to promote the acquisition of assistive technology is restricted, the cost of assistive technologies can be a deterrent to their use in supporting independent life, schooling, and work of people with disabilities (UNESCO, 2013). Access to information through assistive technology must be based on individual needs, without being limited by logistical constraints, service limitations, and funding restrictions.

The results of this study also show that in addition to the benefits of providing assistive technology for disabilities, there are also drawbacks or limitations that need to overcome students as presented in table 2. Another thing that needs to be consider is time management, for example, students with disabilities must prepare their assignments early so they can submit them at the same time as other students and avoid technical obstacles from the media used. As a result, a beneficiary may use this credential to go to any retailer whose goods are more suited for them. According to some experts, a number of companies that can provide an individual option of technical rehabilitation aids may raise the price of their products because the cost of switching to devices from other vendors would increase for the purchaser. Consequently, in accordance with the applicable requirement for purchased goods, the inclusion of the particular requirements or attributes of certain people with disabilities that use ATD must be defined. The option of technological recovery supports will then be individualized without losing interchangeableness and compatibility in products manufactured by various firms. This will promote the adaptation of uniform norms which will have a real effect on the consumer situation in the prospect of substitutes (Goriainova et al., 2020). When accessing information 
through assistive technology, it is necessary to ensure the ability of the student with impairments to utilize the technology in the form of a comprehensive understanding of the media used, so that optimum benefits are obtained.

Information access is the main discourse in the current information era, because success in providing media to access information through technology assistance for students with visual impairments will have a direct impact on freedom and create their independence. Technology provides a space for disability to choose the proper equipment they need to access information so that they are able to complete their education easily and achieve success in studying at university. In the context of this research, the university must ultimately adapt and accommodate the information needs of students with impairments by creating an inclusive environment. These conditions not only benefit students with disabilities but also other students and the academic community in the campus environment.

\section{CONCLUSION}

The access that needs to be provided for blind students is quite broad in scope, not only regarding access to physical buildings but access to information through the help of information and communication technology media. This is very important for students with impairments since it allows them to participate in learning activities on campus independently and achieve the expected success. The presence of assistive technology for student with visual impairment to complete educational tasks is very useful in order to obtain maximum ability from the educational environment. Technology not only helps students with visual disabilities to quickly and easily understand the lecture material delivered in class, but more than that, it can help develop their cognitive, social and communication skills when interacting with the surrounding environment.

\section{REFERENCES}

Baumel., A. (2006). Aksesibilitas. Health Messenger : Pembawa Pesan Kesehatan.

Bungin, B. (2007). Penelitian Kualitatif: Komunikasi, Ekonomi, Kebijakan Publik, dan Ilmu Sosial Lainnya. Kencana.

Drigas Athanasios, Kouremeneous Dimitris, V. J. (2007). Learning Applications for Disabled People" on Technology Enhanced Learning for People With Disabilities: Approaches and Applications (J. Patricia Ordonez de Pablos, JingYuan Zhao, Robert Tennyson, Atkinson, M. T.,\& Dhiensa (ed.)). Chandos Publishing.

Duplaga, M. (2017). Digital divide among people with disabilities: Analysis of data from a nationwide study for determinants of Internet use and activities performed online. PLOS ONE, 12(6), 1-19. https://doi.org/10.1371/journal.pone.0179825

Faizah. (2016). Kualitas Hidup Mahasiswa Disabilitas Angkatan Pertama Dalam Menempuh Pendidikan Di Perguruan Tinggi Inklusi. Jurnal Psikohumanika, 8(2).

Gibbs, G. R. (2021). The Nature of Qualitative Analysis In: Analyzing Qualitative Data. https://doi.org/10.4135/9781526441867

Goriainova, A., Pishnyak, A., \& Khabirova, E. (2020). The Determinants of the Development of Russian Assistive Technologies Market: Analysis of Experts ' Interviews The Determinants of the Development of Russian Assistive Technologies Market: Analysis of Experts ' Interviews. 25(8), 3019-3044.

Kelly, S. M., \& Smith, D. W. (2011). The Impact of Assistive Technology on the Educational Performance of Students with Visual Impairments : A Synthesis of the Research. Journal of Visual Disability \& Blindness, Vol. 10 No(February), 73-83. https://doi.org/10.1177/0145482X1110500205

Mccarthy, T., \& Cutrell, E. (2014). NIH Public Access. 25(4), 222-229.

Mutadho, I. (2018). Analisis Kebijakan Politik Kampus UIN Sunan Kalijaga dan Universitas Gajah Mada bagi partisipasi Mahasiswa Difabel. Unversitas Islam Negeri Sunan Kalijaga. 
Mutia, F. (2020). PENGETAHUAN DAN BIOPOWER DISABILITAS Studi tentang Akses Informasi bagi Mahasiswa Disabilitas Penglihatan di Universitas Airlangga Surabaya dalam Perspektif Foucauldian. UNIVERSITAS AIRLANGGA.

Naraswari, C. C. (2018). Kebermaknaan Hidup Mahasiswa Difabel Unesa yang Menjadi Relawan di Pusat Studi Layanan Disabilitas (PSLD) Universitas Negeri Surabaya. Jurnal Penelitian Psikologi, 5(2).

Patricia Ordóñez de Pablos, Jingyuan Zhao, R. T. (2011). Technology Enhanced Learning for People with Disabilities: Approaches and Applications. IGI Global.

Raja, D. S. (2016). Digital Dividends Bridging the Disability Divide through Digital Technologies.

Smethurst. (1999). Meeting New Demands: The Role of the Library as a centre for education and Research. E-Prints in Library \& Information Science, 37. www.eprints.rclis.org/9760/1/8psab008.pdf

Sunanto, J. (2005). Potensi Anak Berkelainan Penglihatan. Departemen Pendidikan Nasional.

UNESCO. (2013). The ICT Opportunity for a Disability-Inclusive Development Framework: New action-oriented report. UNESCO.Int. http://www.unesco.org/new/en/memberstates/single-

view/news/the_ict_opportunity_for_a_disability_inclusive_development_f/ 